\title{
trans-10,cis-12 Conjugated linoleic acid inhibits lipoprotein lipase but increases the activity of lipogenic enzymes in adipose tissue from hamsters fed an atherogenic diet
}

\author{
Amaia Zabala ${ }^{1}$, Itziar Churruca ${ }^{1}$, Alfredo Fernández-Quintela ${ }^{1}$, Víctor M. Rodríguez ${ }^{1}$, \\ M. Teresa Macarulla ${ }^{1}$, J. Alfredo Martínez ${ }^{2}$ and María P. Portillo ${ }^{1}$ * \\ ${ }^{1}$ Department of Nutrition and Food Science, University of País Vasco, Paseo de la Universidad 7, 01006 Vitoria, Spain \\ ${ }^{2}$ Department of Physiology and Nutrition, University of Navarra, c/ Irunlarrea s/n, 31008 Pamplona, Spain
}

(Received 1 August 2005 - Revised 27 January 2006 - Accepted 7 February 2006)

\begin{abstract}
The aim of the present work was to investigate the effects of trans-10,cis-12 conjugated linoleic acid (CLA) on the activity and expression of lipogenic enzymes and lipoprotein lipase (LPL), as well as on the expression of transcriptional factors controlling these enzymes, in adipose tissue from hamsters, and to evaluate the involvement of these changes in the body fat-reducing effect of this CLA isomer. Thirty male hamsters were divided into three groups and fed atherogenic diets supplemented with 0 (linoleic group), 5 or $10 \mathrm{~g}$ trans-10, cis-12 CLA/kg diet, for 6 weeks. Body and adipose tissue weights, food intake and serum insulin were measured. Total and heparin-releasable LPL and lipogenic enzyme activities (acetyl-CoA carboxylase (ACC); fatty acid synthase (FAS); glucose-6-phosphate dehydrogenase (G6PDH); and malic enzyme (ME)) were assessed. ACC, FAS, LPL, sterol regulatory element-binding proteins (SREBP-1a), SREBP-1c and PPARy mRNA levels were also determined by real-time PCR. CLA did not modify food intake, body weight and serum insulin level. CLA feeding reduced adipose tissue weight, LPL activity and expression, and increased lipogenic enzyme activities, despite a significant reduction in ACC and FAS mRNA levels. The expression of the three transcriptional factors analysed (SREBP-1a, SREBP-1c and PPAR $\gamma$ ) was also reduced. These results appear to provide a framework for partially understanding the reduction in body fat induced by CLA. Inhibition of LPL activity seems to be an important mechanism underlying body fat reduction in hamsters. Further research is needed to better characterize the effects of CLA on lipogenesis and the role of these effects in CLA action.
\end{abstract}

Conjugated linoleic acid: Lipogenesis: Lipoprotein lipase: Adipose tissue

Conjugated linoleic acid (CLA) has been reported as a potent modulator of body composition, especially by reducing the accumulation of body fat into adipose tissue. Although this effect has been observed in several animal models (mouse, rat, hamster, pig, chicken), important differences in their responses to CLA have been described. The vast majority of studies in this area have been done in the mouse, which clearly exhibit an exaggerated response in comparison with other species. Responsiveness of hamster and rat is lower (Roche et al. 2001; Belury, 2002; Evans et al. 2002; Kim et al. 2002).

There is now strong evidence showing that the trans-10,cis12 isomer is mostly responsible for this adipose mass-lowering effect of CLA (Park et al. 1999; Pariza et al. 2000, 2001; Evans et al. 2002; Martin \& Valeille, 2002; Navarro et al. 2003), suggesting that trans-10,cis-12 CLA is likely to be the biologically active isomer in fat management.

The mechanisms by which trans-10,cis-12 CLA exerts this effect have not been completely clarified. A negative energy balance due to decreased energy intake and/or increased energy expenditure may play a role (Pariza et al. 2001; Roche et al. 2001, 2002; Ealey et al. 2002; Takahashi et al. 2002). Moreover, direct effects on adipose tissue metabolic pathways, such as lipolysis, $\beta$-oxidation of fatty acids, triacylglycerol synthesis, fatty acid uptake and pre-adipocyte differentiation may also be involved (Park et al. 1997, 2004; Choi et al. 2000; Martin et al. 2000; Tsuboyama-Kasaoka et al. 2000; Lin et al. 2001; Pariza et al. 2001; Roche et al. 2001; Xu et al. 2003; Macarulla et al. 2005; Simón et al. 2005).

The aim of the present work was to investigate the effects of trans-10,cis12 CLA intake on the activity and expression of several lipogenic enzymes and lipoprotein lipase (LPL) in adipose tissue from hamsters, and to evaluate the potential involvement of these changes in the body fat-reducing effect of this CLA isomer. In order to gain more insight concerning CLA mechanism of action, the effects on the expression of transcriptional factors that regulate the activity of these enzymes (sterol regulatory element-binding proteins (SREBP-1a), SREBP-1c and PPAR $\gamma$ ) was also studied. 


\section{Materials and methods}

\section{Animals, diets and experimental design}

The experiment was conducted with thirty 9-week-old male Syrian Golden hamsters purchased from Harlan Ibérica (Barcelona, Spain) and took place in accordance with the institution's guide for the care and use of laboratory animals. The hamsters were individually housed in polycarbonate metabolic cages (Techniplast Gazzada, Guguggiate, Italy) and placed in an air-conditioned room $\left(22 \pm 2^{\circ} \mathrm{C}\right)$ with a $12 \mathrm{~h}$ light-dark cycle. After a $6 \mathrm{~d}$ adaptation period, hamsters were randomly divided into three dietary groups of ten animals each for feeding varied doses of trans-10,cis-12 CLA as NEFA (0, 0.5 and $1.0 \mathrm{~g} / 100 \mathrm{~g}$ diet) in a semi-purified atherogenic diet consisting of $200 \mathrm{~g} / \mathrm{kg}$ casein (Sigma, St Louis, MO, USA), $4 \mathrm{~g} / \mathrm{kg}$ L-methionine (Sigma), $200 \mathrm{~g} / \mathrm{kg}$ wheat starch (Vencasser, Bilbao, Spain), $405 \mathrm{~g} / \mathrm{kg}$ sucrose (local market), $100 \mathrm{~g} / \mathrm{kg}$ palm oil (Agra-Unilever, Leioa, Spain), $30 \mathrm{~g} / \mathrm{kg}$ cellulose (Vencasser), $4 \mathrm{~g} / \mathrm{kg}$ choline- $\mathrm{HCl}$ (Sigma) and $1 \mathrm{~g} / \mathrm{kg}$ cholesterol (Sigma). trans-10,cis-12 CLA (95\%) was supplied by Natural Lipids Ltd (Hovdebygda, Norway). Vitamin $(11 \mathrm{~g} / \mathrm{kg}$ ) and mineral $(40 \mathrm{~g} / \mathrm{kg})$ mixes were formulated according to AIN-93 guidelines (Reeves et al. 1993) and supplied by ICN Pharmaceuticals (Costa Mesa, CA, USA). The experimental diets were freshly prepared once per/ $\mathrm{N}$ week, gassed with, and stored at $0-4^{\circ} \mathrm{C}$ to avoid rancidity. Fatty acid composition of experimental diets was analysed by GC as we previously described (Zabala et al. 2006), and the results are presented in Table 1. All animals had free access to food and water. Food intake and body weight were measured daily.

At the end of the experimental period (6 weeks) animals were killed under anaesthesia (diethyl ether) and blood was collected by cardiac puncture. Adipose tissues from different anatomical locations (epididymal, perirenal and subcutaneous) were dissected, weighed, sliced and immediately frozen. Serum was obtained from blood samples after centrifugation $(1000 \mathrm{~g}$ for $10 \mathrm{~min}$ at $4^{\circ} \mathrm{C}$ ). Samples were stored at $-80^{\circ} \mathrm{C}$ until analysis

Table 1. Fatty acid composition ( $\mathrm{g} / 100 \mathrm{~g}$ total fatty acids) of experimental diets*

(Mean values with their standard errors)

\begin{tabular}{|c|c|c|c|c|c|c|}
\hline & \multicolumn{2}{|c|}{ Linoleic group } & \multicolumn{2}{|c|}{$\begin{array}{c}0.5 \% \text { CLA } \\
\text { group }\end{array}$} & \multicolumn{2}{|c|}{$\begin{array}{c}1 \% \text { CLA } \\
\text { group }\end{array}$} \\
\hline & Mean & SEM & Mean & SEM & Mean & SEM \\
\hline $12: 0$ & 0.67 & 0.06 & 0.81 & 0.01 & 0.77 & 0.02 \\
\hline $14: 0$ & $1 \cdot 23$ & 0.04 & 1.38 & 0.03 & 1.37 & 0.05 \\
\hline $16: 0$ & $40 \cdot 22$ & 0.98 & 43.78 & 0.09 & 43.01 & 0.33 \\
\hline $16: 1 n-7$ & 0.17 & 0.02 & 0.16 & 0.01 & 0.17 & 0.03 \\
\hline $18: 0$ & 0.16 & 0.07 & 0.18 & 0.03 & 0.14 & 0.08 \\
\hline $18: 1 n-9$ & 35.65 & 0.40 & 36.94 & 0.14 & 38.11 & 0.21 \\
\hline $18: 1 n-7$ & 0.76 & 0.005 & 0.77 & 0.002 & 0.77 & 0.03 \\
\hline $18: 2 n-6$ & $13 \cdot 15$ & 0.20 & 09.69 & 0.04 & 9.83 & 0.05 \\
\hline $18: 3 n-3$ & 0.19 & 0.03 & 0.17 & 0.003 & 0.18 & 0.01 \\
\hline $20: 0$ & 0.40 & 0.05 & 0.38 & 0.004 & 0.36 & 0.02 \\
\hline $\begin{array}{l}\text { cis-9, trans-11 } \\
\text { CLA }\end{array}$ & 0.00 & & 0.039 & 0.002 & 0.039 & 0.005 \\
\hline $\begin{array}{l}\text { trans-10, cis-12 } \\
\text { CLA }\end{array}$ & 0.00 & & $0 \cdot 74$ & 0.05 & $1 \cdot 18$ & 0.14 \\
\hline
\end{tabular}

CLA, conjugated linoleic acid.

* Only fatty acids detected higher than $0.10 \mathrm{~g} / 100 \mathrm{~g}$ total fatty acids are listed.

For details of diets and procedures, see this page.

\section{Serum parameters}

Serum insulin was measured by RIA, using a commercial kit (Linco, St Charles, MO, USA).

\section{Lipogenic activities}

Samples of epididymal adipose tissue $(1.0 \mathrm{~g})$ were homogenized in $2.5 \mathrm{ml}$ buffer (pH 7.6) containing $150 \mathrm{~mm}-\mathrm{KCl}$, $1 \mathrm{mM}-\mathrm{MgCl}_{2}, \quad 10 \mathrm{mM}-\mathrm{N}$-acetyl-cysteine and $0.5 \mathrm{~mm}$-dithiothreitol.

After centrifugation at $100000 \mathrm{~g}$ for $40 \mathrm{~min}$ at $4^{\circ} \mathrm{C}$, the supernatant fraction was used for quantification of enzyme activities. Acetyl-CoA carboxylase (ACC; EC 6.4.1.2), fatty acid synthase (FAS; EC 2.3.1.85), glucose-6-phosphate dehydrogenase (G6PDH; EC 1.1.1.49) and malic enzyme (ME; EC 1.1.1.40) activities were measured as described earlier (Zabala et al. 2004). Enzyme activities were expressed either as nmol $\mathrm{HCO}_{3}^{-}$incorporated (ACC), or as nmol NADPH consumed (FAS) or as nmol NADPH produced (G6PDH and ME), per min per $\mathrm{mg}$ protein and per $\mathrm{g}$ tissue.

\section{Lipoprotein lipase activity}

For total LPL activity determination, homogenates of epididymal adipose tissue $(250 \mathrm{mg})$ were prepared in $750 \mu \mathrm{l} 10 \mathrm{mM}$ HEPES buffer ( $\mathrm{pH} 7.5$ ) containing $1 \mathrm{mM}$-dithiothreitol, $1 \mathrm{~mm}$-EDTA, $250 \mathrm{~mm}$-sucrose and $2 \mathrm{~g} / \mathrm{l}$ heparin and used as enzyme source. Soluble protein in homogenates was determined using bovine serum albumin as standard (Bradford, 1976). For heparin-releasable LPL (HR-LPL) activity determination enzyme source was obtained by incubating $250 \mathrm{mg}$ epididymal adipose tissue in $750 \mu \mathrm{l} 10 \mathrm{~mm}$-HEPES buffer (described earlier) at $37^{\circ} \mathrm{C}$ for $30 \mathrm{~min}$.

Enzyme activity was assessed following the method described by Nilsson-Ehle \& Schotz (1976) with modifications. Briefly, samples $(20 \mu \mathrm{l})$ of tissue homogenate (total LPL) or incubation medium (HR-LPL) were incubated with $20 \mu \mathrm{l} 2.5 \mathrm{M}-\mathrm{NaCl}$ or $20 \mu \mathrm{l} \mathrm{HEPES}$ buffer for $30 \mathrm{~min}$ at $37^{\circ} \mathrm{C}$ under gentle agitation with $160 \mu \mathrm{l}$ emulsified substrate mixture $(\mathrm{pH} 7.5)$ consisting of $27.5 \mathrm{~mm}$-piperazine-1,4-bis(ethanesulfonic acid), $55.5 \mathrm{~mm}-\mathrm{MgCl}_{2}, 0.5 \mathrm{~g} / \mathrm{l}$ fatty acid-free bovine serum albumin (Sigma), $6.4 \mathrm{mCi} / 1\left[{ }^{3} \mathrm{H}\right]$ triolein (Amersham Biosciences, Buckinghamshire, UK), $6.6 \mathrm{~mm}$-triolein (cold) and $33 \mathrm{ml} / 1$ hamster inactivated serum as a source of apo CII. Oleate released by LPL was then separated from intact triolein using a liquid partition system (Belfrage \& Vaughan, 1969). A solution containing $\left[{ }^{14} \mathrm{C}\right]$ oleic acid $(3 \cdot 3 \mu \mathrm{Ci}$; Amersham Biosciences) and $2 \mathrm{~mm}$-oleic acid (cold) was used to calculate oleate recovery. The radioactivity was determined in a Tribarb counter (Beckman Coulter, Fullerton, CA, USA).

LPL (total and HR-LPL) activity was calculated by subtracting non-LPL lipolytic activity in the presence of $\mathrm{NaCl}$ from the total lipolytic activity determined without $\mathrm{NaCl}$ and expressed either as nmol oleate released per min per $\mathrm{g}$ tissue or as nmol oleate released per min per total tissue.

\section{Extraction and analysis of RNA and semi-quantification by reverse transcription- $P C R$}

Total RNA was isolated from $100 \mathrm{mg}$ adipose tissue using Trizol (Invitrogen, Carlsbad, CA, USA) according to the 
manufacturer's instructions. RNA samples were treated with RNase-free DNase I (Takara, Otsu, Japan) to remove any genomic DNA. The yield and quality of the RNA were assessed by measuring absorbance at 260, 270, 280 and $310 \mathrm{~nm}$ and by electrophoresis on $1.3 \%$ agarose gels. Total RNA $(1.5 \mu \mathrm{g})$ was used to synthesize first-strand cDNA using iScriptTM cDNA Synthesis Kit (Bio-Rad, Hercules, CA, USA) that blends polydT and random hexamer primers.

Relative ACC, FAS, SREBP-1a, SREBP-1c, LPL and PPAR $\gamma$ mRNA levels were quantified using real-time PCR with an ABI Prism 7000HT Sequence Detection System (Applied Biosystems). A volume $(0 \cdot 1 \mu \mathrm{l})$ of each cDNA was added to PCR reagent mixture, SYBR ${ }^{\circledR}$ Green Master Mix (Applied Biosystems) with the upstream and downstream primers (300 nM each). Information concerning specific sense and antisense primers are described in Table 2. The PCR parameters were as follows: initial $2 \mathrm{~min}$ at $50^{\circ} \mathrm{C}$; denaturation at $95^{\circ} \mathrm{C}$ for $10 \mathrm{~min}$ followed by forty cycles of denaturation at $95^{\circ} \mathrm{C}$ for $15 \mathrm{~s}$; combined annealing and extension at $60^{\circ} \mathrm{C}$ for $1 \mathrm{~min}$. All samples were normalized to the values of $\beta$ actin and the results expressed as relative fold changes of threshold cycle $(\mathrm{Ct})$ value relative to the linoleic group using the $2^{-\Delta \Delta \mathrm{Ct}}$ method (Livak \& Schmittgen, 2001).

\section{Statistical analysis}

Results are presented as means with their standard errors. Statistical analysis was performed using SPSS version 11.0 (SPSS Inc., Chicago, IL, USA). Data were analysed by one-way ANOVA followed by Newman-Keuls post-hoc test. Statistical significance was set at the $P<0.05$ level.

\section{Results}

Body weight, food intake, adipose tissue weights and serum insulin

No differences in food intake were found among the three experimental groups. Although no significant differences in final body weight were found between hamsters fed the trans-10,cis-12 CLA diets and hamsters fed the linoleic diet, animals fed $1 \%$ CLA showed significantly higher final body weight $(+4.2 \%)$ than those fed $0.5 \%$ CLA $(P<0.05$; Table 3). We previously described that this effect was due to increased skeletal muscle mass (Zabala et al. 2006). CLA feeding significantly reduced adipose tissue weights in epididymal, perirenal and subcutaneous locations. A dose-dependent effect was not observed (Fig. 1).
Concerning serum insulin, no significant differences were observed among the three experimental groups: 567 (SEM 96), 539 (SEM 70) and 546 (SEM 42) pmol/l for the linoleic group, the $0.5 \%$ CLA group and the 1\% CLA group, respectively.

\section{Enzyme activities and enzyme and transcriptional factor expression in epididymal adipose tissue}

CLA feeding significantly reduced the activity (nmol/min per g tissue) of both total LPL and HR-LPL (Fig. 2). Data concerning total tissue capacity (nmol/min per tissue) were 233 (SEM 38) in the linoleic group, 126 (SEM 17) in the $0.5 \%$ CLA group $(P<0.05)$ and 81 (SEM 10) in the $1 \%$ CLA group $(P<0.01)$ for total LPL, and 40 (SEM 6) in the linoleic group, 23 (SEM 3 ) in the $0.5 \%$ CLA group $(P<0.05)$ and 20 (SEM 2) in the $1 \%$ CLA group $(P<0 \cdot 01)$ for HR-LPL. The same effect was observed on LPL mRNA (Fig. 3). Concerning PPAR $\gamma$ expression, both CLA doses induced significant reductions (Fig. 3).

With regard to the activity of the four lipogenic enzymes analysed, significantly greater values were found in hamsters fed the trans-10,cis-12 CLA when compared with those fed the linoleic diet. Because similar trends were observed when activities were expressed per $\mathrm{mg}$ protein or per $\mathrm{g}$ tissue, only those expressed per g tissue are presented (Fig. 4). No differences were found between both doses of CLA.

In order to assess the whole lipogenic potential of epididymal adipose tissue, enzyme activities were also calculated per total tissue weight ( $\mathrm{nmol} / \mathrm{min}$ per tissue): 3170 (SEM 258 ) in the linoleic group, 9225 (SEM 941) in the $0.5 \%$ CLA group and 10135 (SEM 728) in the 1\% CLA group $(P<0.001)$ for G6PDH; 334 (SEM 39) in the linoleic group, 1014 (SEM 50) in the 0.5\% CLA group and 1144 (SEM 101) in the $1 \%$ CLA group $(P<0.001)$ for ME; 207 (SEM 23) in the linoleic group, 496 (SEM 47) in the $0.5 \%$ CLA group and 469 (SEM 41) in the 1\% CLA group $(P<0.001)$ for FAS; 101 (SEM 9) in the linoleic group, 123 (SEM 4) in the $0.5 \%$ CLA group and 137 (SEM 23) in the $1 \%$ CLA group $(P<0.001)$ for ACC.

mRNA of ACC, FAS and the transcriptional factors, SREBP-1a and SREBP-1c, were significantly reduced by CLA feeding (Fig. 5).

\section{Discussion}

trans-10,cis-12 CLA intake produced a significant decrease in adipose tissue weights. The magnitude of this reduction was

Table 2. Primers for PCR amplification gene products of each gene studied

\begin{tabular}{|c|c|c|c|}
\hline Primers & Sense primer & Antisense primer & GenBank accession no. \\
\hline SREBP-1a & 5'-GGCTGTGGAACAGGCACTG-3' & 5'-AGCTGGAGCATGTCTTCGATG-3' & Field et al. (2003) \\
\hline SREBP-1C & 5'-GCGGACGCAGTCTGGG-3' & 5'-ATGAGCTGGAGCATGTCTTCAAA-3' & Field et al. (2003) \\
\hline FAS & 5'-AGCCCCTCAAGTGCACAGTG-3' & 5'-TGCCAATGTGTTTTCCCTGA-3' & AF356086 \\
\hline ACC & 5'-ACACTGGCTGGCTGGACAG- $3^{\prime}$ & 5'-CACACAACTCCCAACATGGTG-3' & AF356089 \\
\hline LPL & 5'-CAGCTGGGCCTAACTTTGAG-3' & 5'- ССTCTCTGCAATCACACGAA-3' & AF356087 \\
\hline PPAR $y$ & 5'-ATTCTGGCCCACCAACTTCGG-3' & 5'-TGGAAGCCTGATGCTTTATCCCCA-3' & AF156665 \\
\hline$\beta$-Actin & 5'-TCTACAATGAGCTGCGTGTG-3' & 5'-GGTCAGGATCTTCATGAGGT-3' & J00691 \\
\hline
\end{tabular}

ACC, acetyl-CoA carboxylase; FAS, fatty acid synthase; LPL, lipoprotein lipase; SREBP, sterol regulatory element-binding protein. 
Table 3. Final body weight, food intake and serum parameters of hamsters fed on the experimental diets for 6 weeks* (Mean values with their standard errors for ten hamsters per group)

\begin{tabular}{|c|c|c|c|c|c|c|c|}
\hline & \multicolumn{2}{|c|}{ Linoleic group } & \multicolumn{2}{|c|}{$0.5 \%$ CLA group } & \multicolumn{2}{|c|}{$1 \%$ CLA group } & \multirow[b]{2}{*}{ Statistical significance of effect (ANOVA) } \\
\hline & Mean & SEM & Mean & SEM & Mean & SEM & \\
\hline Final body weight $(\mathrm{g})$ & $121^{\mathrm{ab}}$ & 3 & $119^{b}$ & 1 & $124^{\mathrm{a}}$ & 2 & $P<0.05$ \\
\hline Food intake $(\mathrm{g} / \mathrm{d})$ & $6 \cdot 03$ & 0.14 & 5.66 & 0.08 & 5.73 & 0.12 & NS \\
\hline
\end{tabular}

${ }^{*}$ For details of diets and procedures, see Table 1 and p. 1113.

a,b,c Mean values within the same row with unlike superscript letters were significantly different $(P<0.05)$.

similar when CLA was added to the diet at either $0.5 \%$ or $1 \%$, perhaps because $0.5 \%$ CLA is sufficient to maximally induce body fat reduction in the hamster.

The present work was designed to shed light on some of the potential mechanisms underlying the decrease of white adipose tissue size, produced by the trans-10, cis-12 CLA

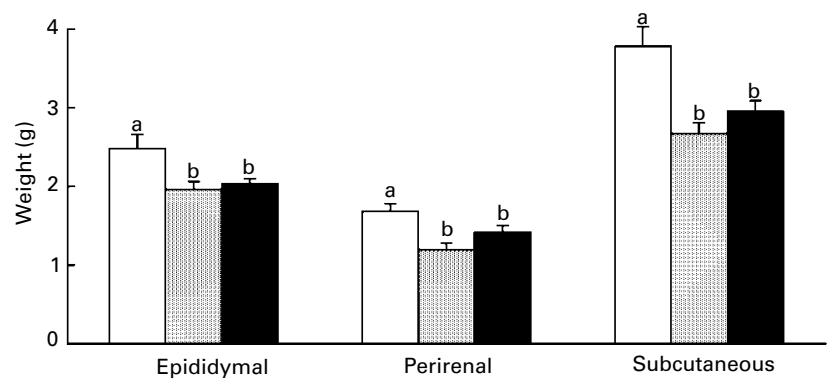

Fig. 1. Epididymal, perirenal and subcutaneous adipose tissue weights from hamsters (ten per group) fed on the experimental diets for 6 weeks. For details of diets and procedures, see Table 1 and p. 1113. Values are means with their standard errors depicted by vertical bars. ${ }^{a, b}$ Mean values with unlike superscript letters were significantly different $(P<0.05)$. $\square$, Linoleic group; $\square, 0.5 \%$ conjugated linoleic acid (CLA) group; $\mathbf{\square}, 1 \%$ CLA group. Decrease in adipose tissue weight: epididymal $(21.0 \%$ in $0.5 \%$ CLA, $P<0.05 ; 18.1 \%$ in $1 \%$ CLA,$P<0.05)$, perirenal $(29.2 \%$ in $0.5 \%$ CLA, $P<0.05 ; 15.5 \%$ in $1 \%$ CLA, $P<0.05)$ and subcutaneous $(29.4 \%$ in $0.5 \%$ CLA, $P<0.001 ; 22.0 \%$ in $1 \%$ CLA, $P<0.001$ )

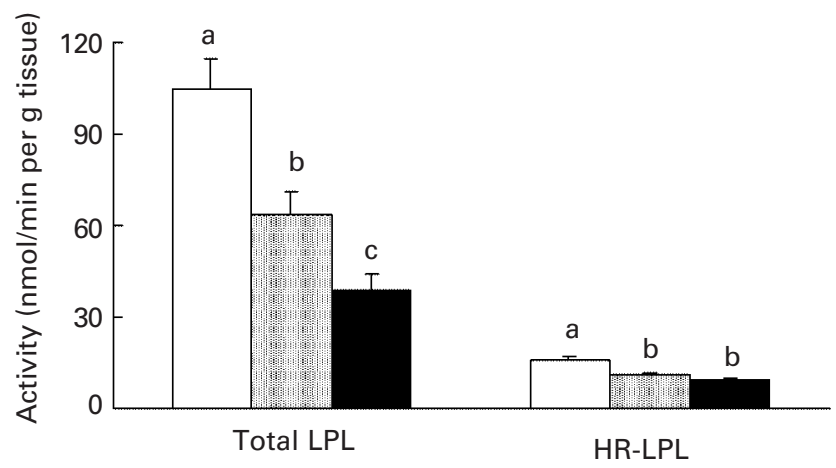

Fig. 2. Total lipoprotein lipase (LPL) and heparin-releasable LPL (HR-LPL) activities in epididymal adipose tissue from hamsters (ten per group) fed on the experimental diets for 6 weeks. For details of diets and procedures, see Table 1 and p. 1113. Values are means with their standard errors depicted by vertical bars. ${ }^{a, b, c}$ Mean values with unlike superscript letters were significantly different $(P<0.05)$. $\square$, Linoleic group; $\square, 0.5 \%$ conjugated linoleic acid (CLA) group; $\mathbf{\square}, 1 \%$ CLA group. Decrease in total and HR-LPL activities: total LPL $(40.0 \%$ in $0.5 \%$ CLA, $P<0.01 ; 62.8 \%$ in $1 \%$ CLA, $P<0.001)$ and HR-LPL $(30.1 \%$ in $0.5 \%$ CLA, $P<0.05 ; 39.7 \%$ in $1 \%$ CLA, $P<0.01)$. isomer. For this purpose mRNA levels, as well as the activities of LPL and several enzymes involved in lipogenesis, were examined.

The effects of CLA on LPL activity have been analysed mainly in cultured cells. Reduced LPL activity in 3T3-L1 adipocytes after supplementation has been reported in several papers (Park et al. 1997, 1999, 2004; Park \& Pariza, 2001). Lin et al. (2001) measured the activity of both intracellular LPL and HR-LPL in 3T3-L1 adipocytes and observed that trans-10, cis-12 CLA only inhibited HR-LPL but not intracellular LPL activity. They concluded that CLA acted at the post-translation stage.

To the best of our knowledge, there are only two in vivo studies in which the effect of CLA on adipose tissue LPL activity was measured. $\mathrm{Xu}$ et al. (2003) reported a significant reduction in both HR-LPL and intracellular LPL activities in adipose tissue from mice fed a $0.5 \%$ CLA mixture-supplemented diet for a very short experimental period (4d), and Faulconnier et al. (2004) found increased LPL activity in perirenal adipose tissue from adult rats, but not in the epididymal depot after 6 weeks of trans-10,cis-12 CLA feeding. Because the results obtained in cultured cells cannot always be extrapolated to in vivo situations, and due to the fact that different sensitivity to CLA has been reported in different rodent species, the present study provides new useful information.

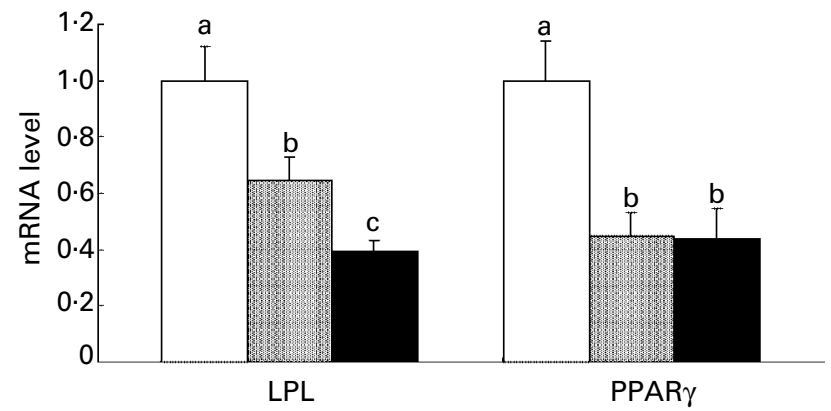

Fig. 3. Lipoprotein lipase (LPL) and PPAR $\gamma$ mRNA levels measured by realtime PCR, in epididymal adipose tissue from hamsters (ten per group) fed on the experimental diets for 6 weeks. For details of diets and procedures, see Table 1 and p. 1113. Values are expressed relative to the linoleic group and results are given as means with their standard errors depicted by vertical bars. ${ }^{a, b}$ Mean values with unlike superscript letters were significantly different $(P<0.05)$. $\square$, Linoleic group; $\square, 0.5 \%$ conjugated linoleic acid (CLA) group; 口, $1 \%$ CLA group. Decrease in LPL and PPAR $y$ mRNA levels: LPL $(35.8 \%$ in $0.5 \%$ CLA, $P<0.05 ; 60.4 \%$ in $1 \%$ CLA, $P<0.001)$ and PPAR $\gamma(55.4 \%$ in $0.5 \%$ CLA,$P<0.01 ; 56.3 \%$ in $1 \%$ CLA,$P<0.01$ ). 

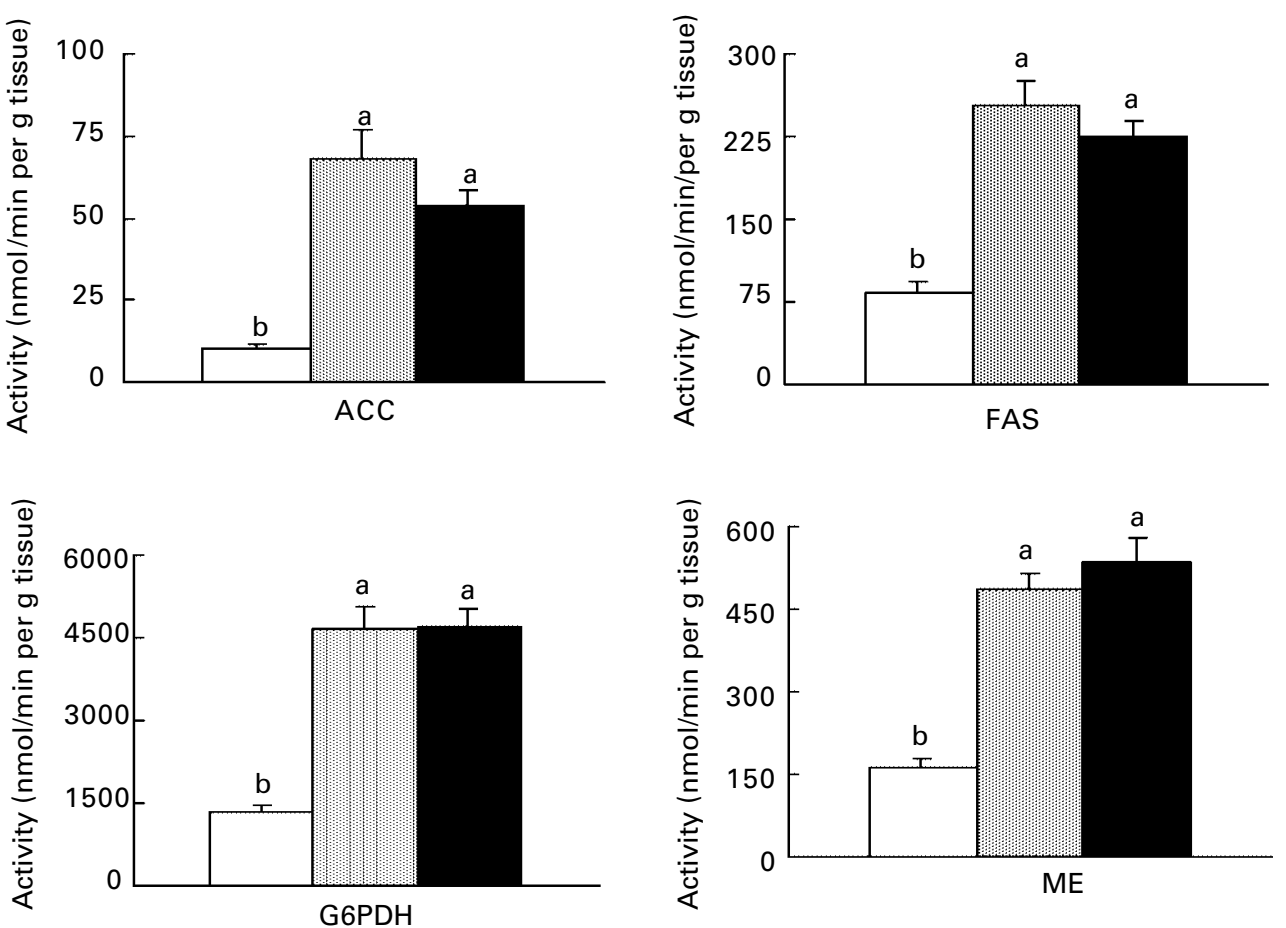

Fig. 4. Lipogenic enzyme activities in epididymal adipose tissue from hamsters (ten per group) fed on the experimental diets for 6 weeks. For details of diets and procedures, see Table 1 and p. 1113. Values are means with their standard errors depicted by vertical bars. ${ }^{a, b}$ Mean values with unlike superscript letters were significantly different $(P<0.05)$. $\square$, Linoleic group; $\square, 0.5 \%$ conjugated linoleic acid (CLA) group; $\mathbf{\square}, 1 \%$ CLA group. ACC, acetyl-CoA carboxylase; FAS, fatty acid synthase; G6PDH, glucose-6-phosphate dehydrogenase; ME, malic enzyme. Increase in lipogenic enzyme activities: G6PDH (249.0\% in 0.5\% CLA, $P<0.001 ; 252.2 \%$ in $1 \%$ CLA, $P<0.001)$, ME (201.9\% in $0.5 \%$ CLA, $P<0.001 ; 233.5 \%$ in $1 \%$ CLA, $P<0.001)$, FAS $(206.0 \%$ in $0.5 \%$ CLA, $P<0.001 ; 170.0 \%$ in $1 \%$ CLA, $P<0.001)$ and ACC (583.8\% in $0.5 \%$ CLA, $P<0.001 ; 445.4 \%$ in $1 \%$ CLA, $P<0.001)$.

The results obtained in hamsters in the present work are thus in good accordance with those found in mice but not in rats. The reduction in LPL activity resulted in diminished adipose tissue size and probably explains, at least in part, the body fat-lowering action of this CLA isomer.

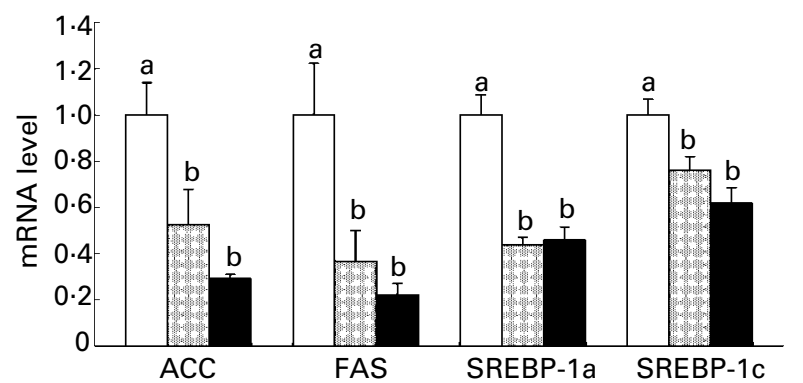

Fig. 5. Acetyl-CoA carboxylase (ACC), fatty acid synthase (FAS), sterol regulatory element-binding protein-1a (SREBP-1a) and SREBP-1c mRNA levels, measured by real-time PCR, in epididymal adipose tissue from hamsters (ten per group) fed on the experimental diets for 6 weeks. For details of diets and procedures, see Table 1 and p. 1113. Values are expressed relative to the linoleic group and results are given as means with their standard errors depicted by vertical bars. ${ }^{a, b}$ Mean values with unlike superscript letters were significantly different $(P<0.05)$. $\square$, Linoleic group; $\square, 0.5 \%$ conjugated linoleic acid (CLA) group; $\mathbf{\square}, 1 \%$ CLA group. Decrease in ACC, FAS, SREBP-1a and SREBP-1c mRNA levels: ACC $(47.6 \%$ in $0.5 \%$ CLA, $P<0.05 ; 70.8 \%$ in $1 \%$ CLA, $P<0.001)$, FAS $(63.4 \%$ in $0.5 \%$ CLA, $P<0.05$; $77.9 \%$ in $1 \%$ CLA, $P<0.001)$, SREBP-1a $(56.3 \%$ in $0.5 \%$ CLA, $P<0.001$; $54.2 \%$ in $1 \%$ CLA, $P<0.001)$, SREBP-1C $(24.0 \%$ in $0.5 \%$ CLA, $P<0.05$; $38.2 \%$ in $1 \%$ CLA, $P<0.01$ ).
The activity of LPL can be regulated at multiple levels including transcription, translation, processing and transport from adipocytes to endothelial cells (Fielding \& Frayn, 1998). Due to the fact that both total and HR-LPL activities were reduced in the CLA-fed groups when compared with the linoleic group, changes in secretion from adipocytes and transport until the capillary endothelial cells does not seem likely. Moreover, the reduction in mRNA levels leads one to the conclusion that the regulation of LPL by CLA takes place at the transcriptional level, which is in good accordance with other works carried out in mice. Tsuboyama-Kasaoka et al. (2000) reported a significant reduction in LPL mRNA level in C57BL/6J mice fed a $1 \%$ CLA mixture-supplemented diet for 8 months, and Kang et al. (2003) observed the same effect in ICR mice fed a $0.5 \%$ CLA mixture-supplemented diet for 4 weeks. In these studies LPL activity was not measured.

PPAR $\gamma$ is a transcriptional factor, highly expressed in adipose tissue compared with muscle or liver (Kersten, 2002), that plays an important role in the regulation of lipid metabolism. Its activation promotes lipid storage by stimulation of LPL (Khan \& Vanden Heuvel, 2003). Thus, in order to obtain more insight concerning the reduction in LPL activity produced by CLA feeding, the expression of this nuclear receptor was assessed in the present work and a significant reduction was observed. These results suggest that the reduction in mRNA LPL induced by CLA feeding can be mediated by the reduced PPAR $\gamma$ expression.

The involvement of PPAR $\gamma$ in the body fat-lowering effect of CLA is a controversial issue. In vitro studies performed in 
3T3-L1 adipocytes and pre-adipocytes have revealed contradictory results concerning the effects of CLA on PPAR $\gamma$ mRNA expression. Thus, whereas Brodie et al. (1999), Brown et al. (2003), Grandlund et al. (2003) and Kang et al. (2003) reported a reduction in PPAR $\gamma$ mRNA levels induced by trans-10,cis-12 CLA, Choi et al. (2000) did not observe any effect. Evans et al. (2001) reported that the effects of trans-10,cis-12 CLA on pre-adipocytes depend on the time period of treatment. Data from in vivo studies are scarcer. Kang et al. (2003) found a reduced PPAR $\gamma$ expression in epididymal adipose tissue from ICR mice fed a $0.5 \%$ CLA mixture and Takahashi et al. (2002) reported the same effect in C57BL/6J mice fed $2 \%$ CLA for $21 \mathrm{~d}$, but not in ICR mice.

In a previous work, we reported increased liver fatty acid oxidation in hamsters fed trans-10,cis-12 CLA (Macarulla et al. 2005). Moreover, several studies performed in HepG2 cells have shown decreased VLDL secretion induced by CLA (Yotsumoto et al. 1999; Pal et al. 2005; Storkson et al. 2005). Thus, in addition to a direct effect of trans-10,cis-12 CLA on PPAR $\gamma$, the potential involvement of decreased availability of VLDL substrate in the reduction of LPL activity should not be discarded. This fact suggests that some of the effects induced by CLA in adipose tissue could be a consequence of changes in liver triacylglycerol metabolism.

With regard to the effects of CLA on adipose tissue lipogenesis, conflicting results have been reported when either enzyme activities or expression were assessed. West et al. (2000) observed increased fatty acid synthesis, despite a significant reduction in adipose tissue weight, in growing mice fed a $1 \%$ CLA mixture. Increased lipogenic enzyme activities, without changes in adipose tissue size, were reported in adult rats fed $1 \%$ trans-10,cis-12 CLA for 6 weeks by Faulconnier et al. (2004). Further, Kang et al. (2004) found an increase in FAS mRNA induced by $0.2 \%$ trans-10, cis- 12 CLA feeding for 4 weeks in mice. In contrast, Azain et al. (2000) did not find changes in FAS activity induced by CLA feeding in rats. Other authors found reduced expression of FAS and ACC in mice (Tsuboyama-Kasaoka et al. 2000; Clement et al. 2002). With regard to non-ruminant species, Corino et al. (2002) described decreased ACC activity, without changes in ME and G6PDH activities in adipose tissue from rabbits fed a CLA mixture. Unfortunately, no works in the literature evaluating both lipogenic enzyme activities and mRNA in the same experiment are available. Thus, we performed both determinations in the same tissue in order to bring some new facts to light on this issue.

In the present work, trans-10,cis-12 CLA feeding significantly reduced the mRNA expression of the two specific lipogenic enzymes measured (ACC, FAS). These results are in good accordance with those published by Tsuboyama-Kasaoka et al. (2000) and Clement et al. (2002) but not with those reported by Kang et al. (2004) in mice. Nevertheless, when comparisons are made among different animals species, it should be taken into account that they differ in the major site of fatty acid synthesis. Whereas, in the rat adipose tissue accounts for over $50 \%$ of total fatty acid synthesis (Waterman et al. 1975), in the mouse the most important lipogenic organ is the liver (Mourot et al. 1994).

SREBP-1a and SREBP-1c are potent activators of enzymes involved in fatty acid synthesis, and have been shown to be affected by nutritional factors (Horton et al. 2002).
The reduction that we found in the mRNA expression of these transcriptional factors, induced by trans-10, cis-12, paralleled changes observed in ACC and FAS.

The activities of the four lipogenic enzymes were surprisingly increased. This effect is in line with that found by West et al. (2000) in mice and Faulconnier et al. (2004) in rats, but disagrees with that reported by Azain et al. (2000) in rats. Obviously, this effect is not one of the potential mechanisms by which CLA reduces adipose tissue size. In our opinion, CLA acts directly by inhibiting the expression of lipogenic enzymes, an effect that is in good accordance with its body fat-lowering effect. On the contrary, the increase in lipogenic enzyme activities could represent a compensatory mechanism as a response to the reduced fatty acid uptake from serum triacylglycerol-rich lipoproteins, due to LPL inhibition. Moreover trans-10,cis-12 CLA has been reported to reduce fatty acid transport in inguinal fat pads from rats (Sauer et al. 2004). The high availability of glucose-6-phosphate, due to the high content of sucrose in the diet, could allow this compensatory phenomenon acting on enzyme activation.

In summary, the results here reported appear to provide a framework for partially understanding the reduction in body fat induced by trans-10,cis-12 CLA intake. Inhibition of LPL activity seems to be a mechanism underlying body fat reduction in hamsters. The possibility of a reduction of this enzyme activity as a consequence of reduced triacylglycerol availability cannot be discarded. Further research is needed to characterize better the effects of CLA on lipogenesis, under different experimental conditions, and the role of these effects in CLA body fat-lowering action.

\section{Acknowledgements}

This study was supported by grants from the Ministerio de Ciencia y Tecnología (BFI2002-00273), the Government of País Vasco (Biogune, Programa Etortek) and the University of País Vasco (00101.125-E-14788/2002 and 9/00101.12515340/2003). Palm oil was a generous gift from Agra-Unilever Foods España S.A. (Leioa, Spain).

\section{References}

Azain MJ, Hausman DB, Sisk MB, Flatt WP \& Jewell DE (2000) Dietary conjugated linoleic acid reduces rat adipose tissue cell size rather than cell number. J Nutr 130, 1548-1554.

Belfrage P \& Vaughan M (1969) Simple liquid-liquid partition system for isolation of labeled oleic acid from mixtures with glycerides. J Lipid Res 10, 341-344.

Belury M (2002) Dietary conjugated linoleic acid in health: physiological mechanisms of action. Annu Rev Nutr 22, 505-531.

Bradford MM (1976) A rapid and sensitive method for the quantitation of microgram quantities of protein utilizing the principle of protein-dye binding. Anal Biochem 72, 248-254.

Brodie AE, Manning VA, Ferguson KR, Jewell DE \& Hu CY (1999) Conjugated linoleic acid inhibits differentiation of pre- and postconfluent 3T3-L1 preadipocytes but inhibits cell proliferation only in preconfluent cells. J Nutr 129, 602-606.

Brown JM, Boysen MS, Jensen SS, Morrison RF, Storkson J, Lea-Currie R, Pariza M, Mandrup S \& McIntosh MK (2003) 
Isomer-specific regulation of metabolism and PPAR $\gamma$ signalling by CLA in human preadipocytes. J Lipid Res 44, 1287-1300.

Choi Y, Kim YC, Han YB, Park Y, Pariza MW \& Ntambi JM (2000) The trans-10,cis-12 isomer of conjugated linoleic acid downregulates stearoyl-CoA desaturase 1 gene expression in 3T3-L1 adipocytes. J Nutr 130, 1920-1924.

Clement L, Poirier H, Niot I, Bocher V, Guerre-Millo M, Krief S, Staels B \& Besnard P (2002) Dietary trans-10,cis-12 conjugated linoleic acid induces hyperinsulinemia and fatty liver in the mouse. J Lipid Res 43, 1400-1409.

Corino C, Mourot J, Magni S, Pastorelli G \& Rosi F (2002) Influence of dietary conjugated linoleic acid on growth, meat quality, lipogenesis, plasma leptin and physiological variables of lipid metabolism in rabbits. J Anim Sci 80, 1020-1028.

Ealey KN, El-Sohemy A \& Archer MC (2002) Effects of dietary conjugated linoleic acid on the expression of uncoupling proteins in mice and rats. Lipids 37, 853-861.

Evans M, Brown J \& McIntosh M (2002) Isomer-specific effect of conjugated linoleic acid (CLA) on adiposity and lipid metabolism. $J$ Nutr Biochem 13, 508-516.

Evans M, Park Y, Pariza M, Curtis L, Kuebler B \& McIntosh M (2001) trans-10,cis-12 Conjugated linoleic acid reduces triglyceride content while differentially affecting peroxisome proliferator activated receptor $\gamma 2$ and P2 expression in 3T3-L1 preadipocytes. Lipids 36, 1223-1232.

Faulconnier Y, Arnal MA, Patureau Mirand P, Chardigny JM \& Chilliard Y (2004) Isomers of conjugated linoleic acid decrease plasma lipids and stimulate adipose tissue lipogenesis without changing adipose weight in post-prandial adult sedentary or trained Wistar rat. J Nutr Biochem 15, 741-748.

Field FJ, Born E \& Mathur SN (2003) Fatty acid flux suppress fatty acid synthesis in hamster intestine independently of SREBP-1 expression. J Lipid Res 44, 1199-1208.

Fielding BA \& Frayn KN (1998) Lipoprotein lipase and the disposition of dietary fatty acids. Br J Nutr 80, 495-502.

Grandlund L, Juvet LK, Pedersen JI \& Nebb HI (2003) Trans10,cis12-conjugated linoleic acid prevents triacylglycerol accumulation in adipocytes by acting as a PPARgamma modulator. $J$ Lipid Res 44, 1441-1452.

Horton JD, Goldstein JL \& Brown MS (2002) SREBPs: activators of the complete program of cholesterol and fatty acid synthesis in the liver. J Clin Invest 109, 1125-1131.

Kang K, Liu W, Albright KJ, Park Y \& Pariza MW (2003) Trans10,cis-12 CLA inhibits differentiation of 3T3-L1 adipocytes and decreases PPARgamma expression. Biochem Biophys Res Commun 303, 795-799.

Kang K, Miyazaki M, Ntambi JM \& Pariza MW (2004) Evidence that the anti-obesity effect of conjugated linoleic acid is independent of effects on stearoyl-CoA desaturase 1 expression and enzyme activity. Biochem Biophys Res Commun 315, 532-537.

Kersten S (2002) Peroxisome proliferator activated receptors and obesity. Eur J Pharmacol 440, 223-234.

Khan SA \& Vanden Heuvel JP (2003) Role of nuclear receptors in the regulation of gene expression by dietary fatty acids (review). $J$ Nutr Biochem 14, 554-567.

Kim MR, Park Y, Albright KJ \& Pariza M (2002) Differential responses of hamsters and rats fed high-fat or low-fat supplemented with conjugated linoleic acid. Nutr Res 22, 715-722.

Lin Y, Kreeft A, Schuurbiers JA \& Draijer R (2001) Different effects of conjugated linoleic acid isomers on lipoprotein lipase activity in 3T3-L1 adipocytes. J Nutr Biochem 12, 183-189.

Livak KJ \& Schmittgen TD (2001) Analysis of relative gene expression data using real-time quantitative PCR and the $2(-$ DeltaDelta $\mathrm{C}(\mathrm{T}))$ method. Methods 25, 402-408.

Macarulla MT, Fernández-Quintela A, Zabala A, Navarro V, Echevarría E, Churruca I, Rodríguez VM \& Portillo MP (2005) The effects of conjugated linoleic acid on liver composition and fatty acid oxidation are isomer dependent in hamster. Nutrition 21, $512-519$.

Martin JC, Grégoire S, Siess MH, Genty M, Chardingy JM, Berdeaux O, Juanéda P \& Sébédio JL (2000) Effects of conjugated linoleic acid isomers on lipid-mobilizing enzymes in male rats. Lipids $\mathbf{3 5}$, 91-98.

Martin JC \& Valeille K (2002) Conjugated linoleic acid: all the same or to everyone its own function? Reprod Nutr Dev 42, 525-536.

Mourot J, Peiniau P \& Mounier A (1994) Effets de l'acide linoléique alimentaire sur l'activité des enzymes de la lipogenèse dans les tissus adipeux chez le porc. Reprod Nutr Dev 34, 213-220.

Navarro V, Zabala A, Macarulla MT, Fernández-Quintela A, Rodríguez VM, Simón E \& Portillo MP (2003) Effects of conjugated linoleic acid on body fat accumulation and serum lipids in hamsters fed an atherogenic diet. J Physiol Biochem 59, 193-199.

Nilsson-Ehle P \& Schotz MC (1976) A stable radioactive substrate emulsion for assay of lipoprotein lipase. J Lipid Res 17, 536-541.

Pal S, Takechi R \& Ho SS (2005) Conjugated linoleic acid suppresses the secretion of atherogenic lipoproteins from human HepG2 liver cells. Clin Chem Lab Med 43, 269-274.

Pariza MW, Park Y \& Cook ME (2000) Mechanism of action of conjugated linoleic acid: evidence and speculation. Proc Soc Exp Biol Med 223, 8-13.

Pariza MW, Park Y \& Cook ME (2001) The biologically active isomers of conjugated linoleic acid. Prog Lipid Res 40, 283-298.

Park Y, Albright KJ, Liu W, Storkson JM, Cook ME \& Pariza MW (1997) Effects of conjugated linoleic acid on body composition in mice. Lipids 32, 853-858.

Park Y \& Pariza MW (2001) The effects of dietary conjugated nonadecadienoic acid on body composition in mice. Biochim Biophys Acta 1533, 171-174.

Park Y, Storkson JM, Albright KJ, Liu W \& Pariza MW (1999) Evidence that the trans-10,cis-12 isomer of conjugated linoleic acid induces body composition changes in mice. Lipids 34, 235-241.

Park Y, Storkson JM, Liu W, Albright KJ, Cook ME \& Pariza MW (2004) Structure-activity relationship of conjugated linoleic acid and its cognates in inhibiting heparin-releasable lipoprotein lipase and glycerol release from fully differentiated 3T3-L1 adipocytes. $J$ Nutr Biochem 15, 561-569.

Reeves PG, Nielsen FH \& Fahey GC Jr (1993) AIN-93 purified diets for laboratory rodents: final report of the American Institute of Nutrition ad hoc writing committee on the reformulation of the AIN-76 rodent diet. $J$ Nutr 123, 1939-1951.

Roche HM, Noone E, Nugent A \& Gibney MJ (2001) Conjugated linoleic acid: a novel therapeutic nutrient? Nutr Res Rev 14, $173-187$.

Roche HM, Noone E, Sewter C, McBennett S, Savage D, Gibney MJ, O'Rahilly S \& Vidal-Puig AJ (2002) Isomer-dependent metabolic effects of conjugated linoleic acid: insights from molecular markers sterol regulatory element-binding protein-1c and LXRalpha. Diabetes 51, 2037-2044.

Sauer LA, Dauchy RT, Blask DE, Krause JA, Davidson LK, Dauchy EM, Welham KJ \& Coupland K (2004) Conjugated linoleic acid isomers and trans fatty acids inhibit fatty acid transport in hepatoma $7288 \mathrm{CTC}$ and inguinal fat pads in Buffalo rats. J Nutr 134, $1989-1997$.

Simón E, Macarulla MT, Fernández-Quintela A, Rodríguez VM \& Portillo MP (2005) Body fat-lowering effect of conjugated linoleic acid is not due to increased lipolysis. J Physiol Biochem, 61, $363-370$.

Storkson JM, Park Y, Cook ME \& Pariza MW (2005) Effects of trans-10, cis-12 conjugated linoleic acid and cognates on apolipoprotein B secretion in HepG2 cells. Nutr Res 25, 387-399.

Takahashi Y, Kushiro M, Shinohara K \& Ide T (2002) Dietary conjugated linoleic acid reduces body fat mass and affects gene expression of proteins regulating energy metabolism in mice. Comp Biochem Physiol B Biochem Mol Biol 133, 395-404. 
Tsuboyama-Kasaoka N, Takahashi M, Tanemura K, Kim HJ, Tange T, Okuyama H, Kasai M, Ikemoto S \& Ezaki O (2000) Conjugated linoleic acid supplementation reduces adipose tissue by apoptosis and develops lipodystrophy in mice. Diabetes 49, 1534-1542.

Waterman RA, Romsos DR, Tsai AC, Miller ER \& Leveille GA (1975) Influence of dietary safflower oil and tallow on growth, plasma lipids and lipogenesis in rats, pig and chicks. Proc Soc Exp Biol Med 150, 347-351.

West DB, Blohm FY, Truett AA \& DeLany JP (2000) Conjugated linoleic acid persistently increases total energy expenditure in AKR/J mice without increasing uncoupling protein gene expression. J Nutr 130, 2471-2477.

Xu X, Storkson J, Kim S, Sugimoto K, Park Y \& Pariza MW (2003) Short-term intake of conjugated linoleic acid inhibits lipoprotein lipase and glucose metabolism but does not enhance lipolysis in mouse adipose tissue. $J$ Nutr 133, 663-667.

Yotsumoto H, Hara E, Naka S, Adlof RO, Emken EA \& Yanagita T (1999) 10trans, 12cis-Linoleic acid reduced apolipoprotein B secretion in HepG2 cells. Food Res Int 31, 403-409.

Zabala A, Fernández-Quintela A, Macarulla MT, Simón E, Rodríguez VM, Navarro V \& Portillo MP (2006) Effects of conjugated linoleic acid on skeletal muscle triacylglycerol metabolism in hamsters. Nutrition, (In the Press).

Zabala A, Churruca I, Macarulla MT, Rodríguez VM, FernándezQuintela A, Martínez JA \& Portillo MP (2004) The trans-10,cis12 isomer of conjugated linoleic acid reduces hepatic triacylglycerol content without affecting lipogenic enzymes in hamsters. Br J Nutr 92, 383-389. 